\title{
MORTALITY FROM RHEUMATIC HEART DISEASE IN CHILDREN AND YOUNG ADULTS IN ENGLAND AND WALES
}

\author{
BY \\ J. KNOWELDEN* \\ From the Department of Medical Statistics, London School of Hygiene and Tropical Medicine
}

\section{INTRODUCTION}

In the last few years considerable attention has been paid to the rheumatic diseases and, in particular, rheumatic fever. Glover $(1943,1946)$ has shown that the mortality from the latter has declined considerably in the last sixty years and that recently this decline has been accelerated. On these grounds he called acute rheumatism an obsolescent disease. In contrast, Morris and Titmuss (1942), Parkinson (1945), and Ryle (1946) have called attention to the heavy toll still taken by rheumatic heart disease, and to the fact that adolescents and young adults are its main victims.

Considerable local and regional differences in the mortality from rheumatic heart disease have been observed in England and Wales (and also in morbidity), and in an attempt to determine the aetiology many workers have related these differences to social and environmental conditions. Poverty has been among the chief factors incriminated. Reports issued some twenty years ago by the Ministry of Health (1927) and the Medical Research Council (1927) agree that acute rheumatism rarely attacks the children of well-to-do parents. Morris and Titmuss hold the view that " the whole complex of poverty " is involved in the production of juvenile rheumatism, and Daniel (1943), in his study of rheumatic heart disease in Bristol, concluded that there was a significant association between its incidence and low family income. The suggestion in the Medical Research Council's report that the incidence was greatest in the artisan class is supported by Wilson (1940) but denied by Morris and Titmuss.

Bad housing has also been condemned as a cause of acute rheumatism, but the evidence incriminating dampness, ill-ventilation, living in basements, and other features is not clear. Overcrowding is often associated with bad housing, and some authorities have held this factor to be important. In the

\footnotetext{
* Holding a Rockefeller Foundation Fellowship.
}

Medical Research Council's inquiry (1927) no difference was found in overcrowding levels between rheumatic and non-rheumatic families, and Morris and Titmuss, comparing the mortality rates from heart disease in regions of England and Wales, found the correlation with overcrowding inconclusive. Savage (1931) also found no significant association between the incidence of rheumatic heart disease and crowding but, on the other hand, Perry and Roberts (1937) showed that the incidence of rheumatic heart disease in different wards of Bristol was highly and significantly correlated with the average number of persons per room. Daniel, in his more detailed study of the same city, confirmed this relationship. Clarke (1940) considered that in Dublin juvenile rheumatism was not essentially a disease of poverty but coincided with overcrowding and proximity to low-lying areas.

The importance of other factors such as climate, nutrition, maternal care, and heredity is difficult to assess but each has been considered by various authors. It is, therefore, impossible to reach definite conclusions from the evidence already available and, in particular, it seems that more information is required on the effects of poverty and housing. In this respect it would clearly be preferable to study the morbidity from rheumatic heart disease and its relation to these factors, but as yet notification of rheumatic fever and its sequelae is too recent and too localized to be of value. Morbidity statistics are otherwise dependent on special surveys, such as those of Savage, Perry and Roberts, and Daniel. The present study, therefore, is limited to mortality data published by the Registrar-General for England and Wales.

\section{The Available Mortality Data}

In the Annual Statistical Reviews of the RegistrarGeneral there is no separate classification of deaths due to rheumatic heart disease before 1940, when the fifth Revision of the International List of Causes of Death was introduced. Even then only those 
TABLE I

Mortality from Rheumatic FeVter in. England and Wales, 1921-38

\begin{tabular}{|c|c|c|c|c|c|c|c|c|c|}
\hline & \multicolumn{3}{|c|}{$5-14$ years } & \multicolumn{3}{|c|}{$15-24$ years } & \multicolumn{3}{|c|}{$25-34$ years } \\
\hline & $\begin{array}{c}\text { Total } \\
\text { deaths in } \\
\text { triennium }\end{array}$ & $\begin{array}{c}\text { Average } \\
\text { annual } \\
\text { death rate } \\
\text { per million } \\
\text { persons } \\
\text { living }\end{array}$ & $\begin{array}{c}\% \text { of } \\
1921-23 \\
\text { rate }\end{array}$ & $\begin{array}{c}\text { Total } \\
\text { deaths in } \\
\text { triennium }\end{array}$ & \begin{tabular}{|c|} 
Average \\
annual \\
death rate \\
per million \\
persons \\
living
\end{tabular} & $\begin{array}{c}\% \text { of } \\
1921-23 \\
\text { rate }\end{array}$ & $\begin{array}{c}\text { Total } \\
\text { deaths in } \\
\text { triennium }\end{array}$ & $\begin{array}{c}\text { Average } \\
\text { annual } \\
\text { death rate } \\
\text { per million } \\
\text { persons } \\
\text { living }\end{array}$ & $\begin{array}{l}\% \text { of } \\
1921-23 \\
\text { rate }\end{array}$ \\
\hline $\begin{array}{l}\text { Males } \\
1921-23 \\
1924-26 \\
1927-29 \\
1930-32 \\
1933-35 \\
1936-38\end{array}$ & $\begin{array}{l}754 \\
753 \\
671 \\
594 \\
582 \\
456\end{array}$ & $\begin{array}{l}71 \\
75 \\
66 \\
60 \\
59 \\
49\end{array}$ & $\begin{array}{r}100 \\
106 \\
93 \\
85 \\
83 \\
69\end{array}$ & $\begin{array}{l}489 \\
513 \\
422 \\
395 \\
334 \\
319\end{array}$ & $\begin{array}{l}51 \\
51 \\
41 \\
39 \\
35 \\
32\end{array}$ & $\begin{array}{r}100 \\
100 \\
80 \\
76 \\
69 \\
63\end{array}$ & $\begin{array}{l}282 \\
217 \\
194 \\
197 \\
198 \\
187\end{array}$ & $\begin{array}{l}36 \\
27 \\
23 \\
22 \\
20 \\
19\end{array}$ & $\begin{array}{r}100 \\
75 \\
64 \\
61 \\
56 \\
53\end{array}$ \\
\hline $\begin{array}{c}\text { Females } \\
1921-23 \\
1924-26 \\
1927-29 \\
1930-32 \\
1933-35 \\
1936-38\end{array}$ & $\begin{array}{l}840 \\
926 \\
808 \\
655 \\
720 \\
573\end{array}$ & $\begin{array}{l}80 \\
94 \\
81 \\
68 \\
74 \\
63\end{array}$ & $\begin{array}{r}100 \\
118 \\
101 \\
85 \\
93 \\
79\end{array}$ & $\begin{array}{l}658 \\
637 \\
588 \\
504 \\
468 \\
362\end{array}$ & $\begin{array}{l}63 \\
60 \\
56 \\
48 \\
48 \\
37\end{array}$ & $\begin{array}{r}100 \\
95 \\
89 \\
76 \\
76 \\
59\end{array}$ & $\begin{array}{l}295 \\
320 \\
297 \\
276 \\
256 \\
206\end{array}$ & $\begin{array}{l}31 \\
33 \\
30 \\
27 \\
25 \\
20\end{array}$ & $\begin{array}{r}100 \\
106 \\
97 \\
87 \\
81 \\
65\end{array}$ \\
\hline
\end{tabular}

deaths for which rheumatism was specifically mentioned on the death certificate are so classified, excluding many for which a rheumatic origin is implied but not stated. From 1921 to 1930 the third Revision (1920) of the International List was in use, and from 1931 to 1939 the fourth Revision (1929). Both these lists include a group of causes, "Heart Diseases," for which deaths are tabulated for different administrative areas-county and other boroughs, counties, urban and rural districts. For the country as a whole the Registrar-General at the same time tabulated the deaths in sub-divisions of this large group. Although the change from the third to the fourth Revision of the International List involved alterations in the sub-divisions, the whole group, Heart Diseases, was practically identical in the two lists. Thus the deaths from heart disease in England and Wales were classified under the following sub-divisions in the fourth Revision: International List No. 90 Pericarditis.

\begin{tabular}{|c|c|c|c|}
\hline & & & \\
\hline & & No. 91 & Acute endocarditis. \\
\hline & & No. 92 & $\begin{array}{l}\text { Chronic endocarditis, } \\
\text { valvular disease. }\end{array}$ \\
\hline & " & No. 93 & $\begin{array}{l}\text { Diseases of the myo- } \\
\text { cardium. }\end{array}$ \\
\hline & " & No. 94 & $\begin{array}{l}\text { Diseases of the coronary } \\
\text { arteries, angina pec- } \\
\text { toris. }\end{array}$ \\
\hline & ", & No. 95 & $\begin{array}{l}\text { Other diseases of the } \\
\text { heart. }\end{array}$ \\
\hline
\end{tabular}

In young persons the deaths from the first threeo sub-divisions, numbers 90,91 , and 92 , are almost entirely rheumatic in origin, while those due too causes numbers 93 and 94 are generally not rheum- $\frac{0}{8}$ atic. Tabulation of the deaths for the years 1931-33 shows that at ages 5 to 14 years over 90 pero cent. of deaths debited to heart disease fell under 3 the headings of numbers 90,91 , and 92 . At ages 15 to 24 years 86 per cent. were so classified, and at. ages 25 to 34 years 76 per cent. On the other hando at ages 35 to 44 years the proportion falls to only? 54 per cent. It can reasonably be assumed, therefore, $\frac{}{3}$ that, up to the age group 25 to 34 years, the broad group entitled heart diseases, is a fair measure of the mortality from rheumatic heart disease. This is in confirmation of the generally accepted opinion that below 40 years of age nearly all deaths from heart disease are of rheumatic origin.

It may also be noted that the mortality rates used in this study have not been extended beyond 1938 for two reasons: (a) In subsequent years both the deaths recorded in the Statistical Reviews and thew estimated populations of England and Wales refer only to civilians. (Even where a separate tableo shows the number of deaths among non-civilians $\mathbb{D}$ the population at risk is not readily obtainable.) In two of the age groups to be studied the rejection from service in the Armed Forces of those physically? unfit might well have influenced the recorded? mortality rates considerably, particularly as hearto 
disease or previous rheumatic fever was a common ground for rejection; $(b)$ a further complication lay in the introduction by the Registrar-General in 1940 of the fifth Revision (1938) of the International List already mentioned, and also in the change made at the same time in the manner of selecting the assigned cause for tabulation when more than one cause is mentioned on the death certificate. The effect of these changes has been to reduce the number of deaths assigned to heart diseases, so that rates for 1940 and later years are not directly comparable with those up to 1939 . Conversion ratios calculated and published by the Registrar-General for comparison of rates before and after 1940 are applicable to rates at all ages but could not safely be used for the selected age groups studied here or for particular areas.

The Trend of Mortality in England and Wales

Table I shows the average annual mortality rates from rheumatic fever per million persons living (males and females separately) in England and Wales for each of the six triennia 1921-23 to 1936-38 for the age groups 5 to 14,15 to 24 , and 25 to 34 years. Table II is similarly prepared to show the mortality from heart diseases, while Table III combines the two. One clear characteristic of the rates shown in these tables is their rather higher level for females compared with males. Owing to some sex differences in the time trends of mortality the female excess varies somewhat in degree but, apart from the triennium 1921-23, it is invariably present. Ignoring this triennium the total rate for rheumatic fever and heart disease combined shows an almost constant female excess mortality of 20-25 per cent. at ages 5 to 14, a similar though rather more varying excess of 15 to 25 per cent. at ages 15 to 24 , and one of 20 to 30 per cent. at ages 25 to 34 . The discrepancy in 1921-23, in which years the rates on males aged 15 to 24 and 25 to 34 appear unduly high, might possibly be a function of the 1914-18 war, through males being thereby more exposed to the risks of contracting rheumatic fever and of subsequently dying from it. In view of this curiously high and seemingly abnormal rate on males it will also be as well to consider the trend of their mortality from 1924-26 onwards, though the rates have, it will be noted, been expressed as a ratio to those of 1921-23.

Turning to this trend (see also Figs. 1 and 2) the following characteristics may be observed:

(a) Ages 5 to 14. Mortality rates both from rheumatic fever and from heart disease were declining between 1924-26 and 1930-32. There was, however, a clear set-back, with a rise in mortality, in 1933-35; this was followed by an accelerated decline. Taking the combined deaths of Table III, both sexes show a reduction of mortality of nearly one-third between 1921-23 and 1936-38, and their movements throughout the period have been almost identical.

TABLE II

Mortality from Heart Disease in England and Wales, 1921-38

\begin{tabular}{|c|c|c|c|c|c|c|c|c|c|}
\hline & \multicolumn{3}{|c|}{$5-14$ years } & \multicolumn{3}{|c|}{$15-24$ years } & \multicolumn{3}{|c|}{$25-34$ years } \\
\hline & $\begin{array}{c}\text { Total } \\
\text { deaths in } \\
\text { triennium }\end{array}$ & $\begin{array}{c}\text { Average } \\
\text { annual } \\
\text { death rate } \\
\text { per million } \\
\text { persons } \\
\text { living }\end{array}$ & $\begin{array}{c}\% \text { of } \\
1921-23 \\
\text { rate }\end{array}$ & $\begin{array}{c}\text { Total } \\
\text { deaths in } \\
\text { triennium }\end{array}$ & $\begin{array}{c}\text { Average } \\
\text { annual } \\
\text { death rate } \\
\text { per million } \\
\text { persons } \\
\text { living }\end{array}$ & $\begin{array}{c}\% \text { of } \\
1921-23 \\
\text { rate }\end{array}$ & $\begin{array}{c}\text { Total } \\
\text { deaths in } \\
\text { triennium }\end{array}$ & $\begin{array}{c}\text { Average } \\
\text { annual } \\
\text { death rate } \\
\text { per million } \\
\text { persons } \\
\text { living }\end{array}$ & $\begin{array}{c}\% \text { of } \\
1921-23 \\
\text { rate }\end{array}$ \\
\hline $\begin{array}{l}\text { Males } \\
1921-23 \\
1924-26 \\
1927-29 \\
1930-32 \\
1933-35 \\
1936-38\end{array}$ & $\begin{array}{r}1,287 \\
1,130 \\
1,068 \\
950 \\
1,047 \\
757\end{array}$ & $\begin{array}{r}122 \\
113 \\
106 \\
96 \\
105 \\
81\end{array}$ & $\begin{array}{r}100 \\
93 \\
87 \\
79 \\
86 \\
66\end{array}$ & $\begin{array}{l}2,261 \\
1,895 \\
1,950 \\
1,929 \\
1,816 \\
1,741\end{array}$ & $\begin{array}{l}237 \\
188 \\
189 \\
189 \\
187 \\
177\end{array}$ & $\begin{array}{r}100 \\
79 \\
80 \\
80 \\
79 \\
75\end{array}$ & $\begin{array}{l}3,163 \\
2,200 \\
2,246 \\
2,239 \\
2,388 \\
2,317\end{array}$ & $\begin{array}{l}407 \\
278 \\
270 \\
245 \\
243 \\
232\end{array}$ & $\begin{array}{r}100 \\
68 \\
66 \\
60 \\
60 \\
57\end{array}$ \\
\hline $\begin{array}{c}\text { Females } \\
1921-23 \\
1924-26 \\
1927-29 \\
1930-32 \\
1933-35 \\
1936-38\end{array}$ & $\begin{array}{r}1,668 \\
1,355 \\
1,316 \\
1,212 \\
1,258 \\
902\end{array}$ & $\begin{array}{r}159 \\
137 \\
133 \\
125 \\
129 \\
99\end{array}$ & $\begin{array}{r}100 \\
86 \\
84 \\
79 \\
81 \\
62\end{array}$ & $\begin{array}{l}2,353 \\
2,312 \\
2,500 \\
2,475 \\
2,285 \\
2,042\end{array}$ & $\begin{array}{l}225 \\
218 \\
236 \\
236 \\
232 \\
207\end{array}$ & $\begin{array}{r}100 \\
97 \\
105 \\
105 \\
103 \\
92\end{array}$ & $\begin{array}{l}2,972 \\
2,989 \\
3,124 \\
3,254 \\
3,264 \\
3,110\end{array}$ & $\begin{array}{l}314 \\
309 \\
318 \\
324 \\
315 \\
297\end{array}$ & $\begin{array}{r}100 \\
98 \\
101 \\
103 \\
100 \\
95\end{array}$ \\
\hline
\end{tabular}




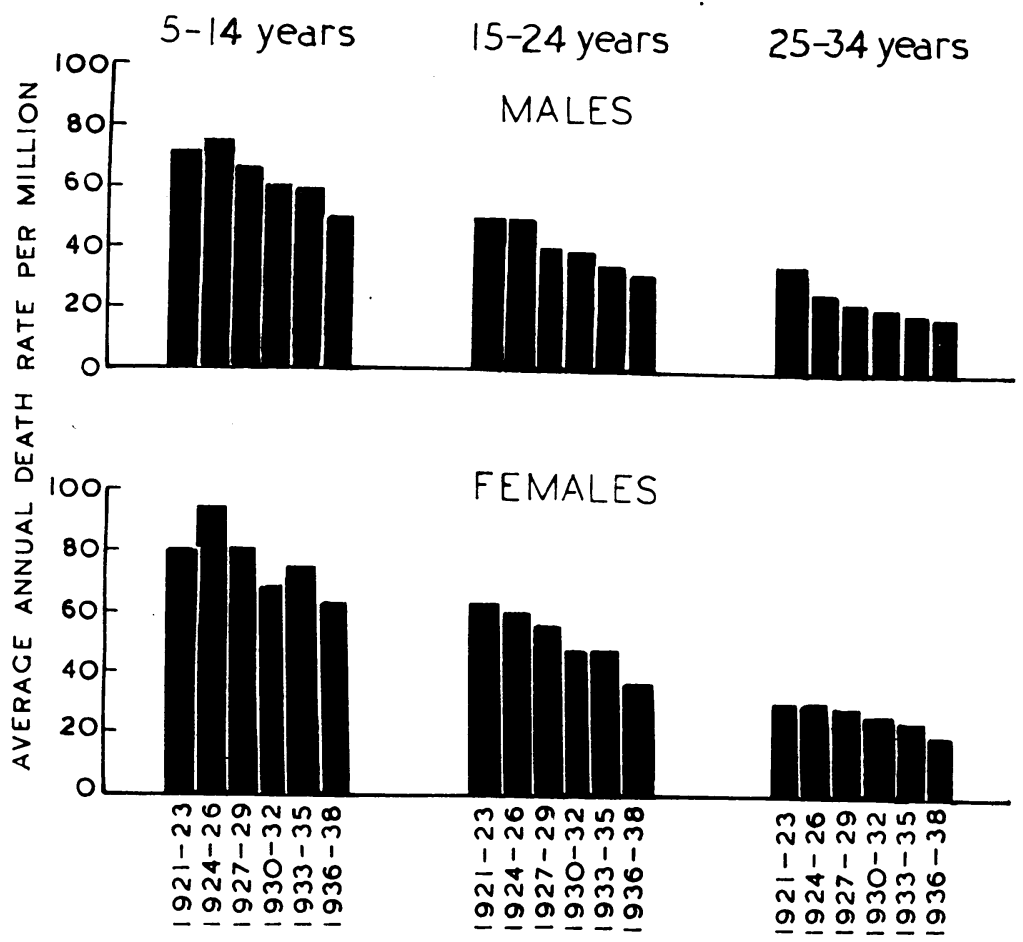

FIG. 1.- The trends in mortality from rheumatic fever in England and Wales, $1921-38$, in age groups 5 to 14,15 to 24 , and 25 to 34 years.

TABLE III

Mortality from Rheumatic Fever and Heart Disease combined in England and Wales, 1921-38

\begin{tabular}{|c|c|c|c|c|c|c|c|c|c|}
\hline & & $5-14$ years & & & $15-24$ years & & & $25-34$ years & \\
\hline & $\begin{array}{c}\text { Total } \\
\text { deaths in } \\
\text { triennium }\end{array}$ & $\begin{array}{c}\text { Average } \\
\text { annual } \\
\text { death rate } \\
\text { per million } \\
\text { persons } \\
\text { living }\end{array}$ & $\begin{array}{c}\% \text { of } \\
1921-23 \\
\text { rate }\end{array}$ & $\begin{array}{c}\text { Total } \\
\text { deaths in } \\
\text { triennium }\end{array}$ & $\begin{array}{c}\text { Average } \\
\text { annual } \\
\text { death rate } \\
\text { per million } \\
\text { persons } \\
\text { living }\end{array}$ & $\begin{array}{c}\% \text { of } \\
1921-23 \\
\text { rate }\end{array}$ & $\begin{array}{c}\text { Total } \\
\text { deaths in } \\
\text { triennium }\end{array}$ & $\begin{array}{c}\text { Average } \\
\text { annual } \\
\text { death rate } \\
\text { per million } \\
\text { persons } \\
\text { living }\end{array}$ & $\begin{array}{c}\% \text { of } \\
1921-23 \\
\text { rate }\end{array}$ \\
\hline $\begin{array}{l}\text { Males } \\
1921-23 \\
1924-26 \\
1927-29 \\
1930-32 \\
1933-35 \\
1936-38\end{array}$ & $\begin{array}{l}2,041 \\
1,883 \\
1,739 \\
1,544 \\
1,629 \\
1,213\end{array}$ & $\begin{array}{l}193 \\
188 \\
172 \\
156 \\
164 \\
130\end{array}$ & $\begin{array}{r}100 \\
97 \\
89 \\
81 \\
85 \\
67\end{array}$ & $\begin{array}{l}2,750 \\
2,408 \\
2,372 \\
2,324 \\
2,150 \\
2,060\end{array}$ & $\begin{array}{l}288 \\
239 \\
230 \\
228 \\
222 \\
209\end{array}$ & $\begin{array}{r}100 \\
83 \\
80 \\
79 \\
77 \\
73\end{array}$ & $\begin{array}{l}3,445 \\
2,417 \\
2,440 \\
2,436 \\
2,586 \\
2,504\end{array}$ & $\begin{array}{l}443 \\
306 \\
294 \\
267 \\
263 \\
251\end{array}$ & $\begin{array}{r}100 \\
69 \\
66 \\
60 \\
59 \\
57\end{array}$ \\
\hline $\begin{array}{c}\text { Females } \\
1921-23 \\
1924-26 \\
1927-29 \\
1930-32 \\
1933-35 \\
1936-38\end{array}$ & $\begin{array}{l}2,508 \\
2,281 \\
2,124 \\
1,867 \\
1,978 \\
1,475\end{array}$ & $\begin{array}{l}240 \\
230 \\
214 \\
192 \\
203 \\
162\end{array}$ & $\begin{array}{r}100 \\
96 \\
89 \\
80 \\
85 \\
68\end{array}$ & $\begin{array}{l}3,011 \\
2,949 \\
3,088 \\
2,979 \\
2,753 \\
2,404\end{array}$ & $\begin{array}{l}288 \\
278 \\
292 \\
285 \\
280 \\
244\end{array}$ & $\begin{array}{r}100 \\
97 \\
101 \\
99 \\
97 \\
85\end{array}$ & $\begin{array}{l}3,267 \\
3,309 \\
3,421 \\
3,530 \\
3,520 \\
3,316\end{array}$ & $\begin{array}{l}345 \\
342 \\
348 \\
351 \\
340 \\
317\end{array}$ & $\begin{array}{r}100 \\
99 \\
101 \\
102 \\
99 \\
92\end{array}$ \\
\hline
\end{tabular}


(b) Ages 15 to 24. At these ages the trend has clearly been less favourable than that found for schoolchildren. The death rates attributed directly to rheumatic fever have, it is true, declined more rapidly than at ages 5 to 14 , but those due to heart disease-and these form the larger componenthave shown practically no change in either sex between 1924-26 and 1936-38. The sum of the two shows a slightly falling rate for males from 1924-26 onwards (ignoring the unduly high rate of 1921-23), while for females there is virtually no change between 1921-23 and 1933-35 but some decline in the final three years, 1936-38.

(c) Ages 25 to 34 . These ages give very much the same picture as the previous group, namely a steady and considerable decline in the deaths attributed directly to rheumatic fever from 1924-26 onwards but relatively little change, particularly for women, in heart disease, which is numerically much the more important group. In total, therefore (again ignoring for reasons given the male figure for 1921-23) there has been only a slight decline in the death rate of males and practically no improvement at all in the death rate of females.

This general inter-war picture is hardly a favourable one. It seems that the substantial fall since 1924-26 in rheumatic fever mortality in each age group and for each sex was largely offset except at the school ages by the lack of decline in the mortality from the heart disease attributable to rheumatic fever. At the school ages, 5 to 14 , there was indeed quite substantial improvement in total though some of this was concentrated in a rather sharp fall in the final period 1936-38. At ages 15 to 24 and 25 to 34 there was likewise an improvement in 1936-38; but, apart from this, male mortality was declining only very slowly and female mortality was not declining at all.

\section{Mortality in Administrative Areas}

It is possible to extend, at least in part, this study of the time changes in mortality since the RegistrarGeneral publishes deaths in regions, county boroughs and rural and urban districts of counties according to an abridged list of causes which includes heart disease as one group. This list does not include rheumatic fever which must, therefore, be left out of account. The average annual mortality rates from heart disease have accordingly been calculated for London Administrative County, all County Boroughs, all Urban Districts, and all Rural Districts for the three age groups under study and for the periods 1920-22, 1930-32, and 1936-38. For the first two periods the average annual deaths in the three years were divided by the census populations of 1921 and 1931 respectively. In the last period the populations had to be estimated on the assumption that the age distribution in all County Boroughs, Urban, and Rural Districts was the same as that in the County Boroughs, Urban, and Rural Districts outside Greater London, estimates of these latter populations being given by age and sex in the Registrar-General's Text volume. These rates and corresponding figures for all England and Wales are set out in Tables IV, V, and VI and shown graphically in Fig. 3.

The level of mortality in relation to urbanization may first be noted, and it will be seen that in each of the three age groups London Administrative County had the highest rate in 1920-22 (except

TABLE IV

Mortality from Heart Disease, 5 to 14 years, in Administrative Regions of England and Wales in the TRIENNIA 1920-22, 1930-32, AND 1936-38

\begin{tabular}{|c|c|c|c|c|c|c|c|c|c|c|}
\hline & \multicolumn{5}{|c|}{ Males } & \multicolumn{5}{|c|}{ Females } \\
\hline & \multicolumn{5}{|c|}{ Average annual death rate per million persons living } & \multicolumn{5}{|c|}{ Average annual death rate per million persons living } \\
\hline & $\begin{array}{c}\text { England } \\
\text { and } \\
\text { Wales }\end{array}$ & $\begin{array}{l}\text { London } \\
\text { Adminis- } \\
\text { trative } \\
\text { County }\end{array}$ & $\begin{array}{l}\text { County } \\
\text { Boroughs }\end{array}$ & $\begin{array}{l}\text { Urban } \\
\text { Districts }\end{array}$ & $\begin{array}{c}\text { Rural } \\
\text { Districts }\end{array}$ & $\begin{array}{c}\text { England } \\
\text { and } \\
\text { Wales }\end{array}$ & $\begin{array}{l}\text { London } \\
\text { Adminis- } \\
\text { trative } \\
\text { County }\end{array}$ & $\begin{array}{l}\text { County } \\
\text { Boroughs }\end{array}$ & $\begin{array}{c}\text { Urban } \\
\text { Districts }\end{array}$ & $\begin{array}{c}\text { Rural } \\
\text { Districts }\end{array}$ \\
\hline \multirow[t]{2}{*}{$\begin{array}{l}1920-22 \\
1930-32 \\
1936-38\end{array}$} & $\begin{array}{r}132 \\
96 \\
81\end{array}$ & $\begin{array}{r}182 \\
94 \\
100\end{array}$ & $\begin{array}{l}148 \\
116 \\
103\end{array}$ & $\begin{array}{r}134 \\
97 \\
69\end{array}$ & $\begin{array}{l}76 \\
63 \\
57\end{array}$ & $\begin{array}{r}173 \\
125 \\
99\end{array}$ & $\begin{array}{r}236 \\
140 \\
99\end{array}$ & $\begin{array}{l}207 \\
148 \\
126\end{array}$ & $\begin{array}{r}160 \\
120 \\
90\end{array}$ & $\begin{array}{r}104 \\
88 \\
64\end{array}$ \\
\hline & \multicolumn{5}{|c|}{ Rate as percentage of $1920-22$ rate } & \multicolumn{5}{|c|}{ Rate as percentage of $1920-22$ rate } \\
\hline $\begin{array}{l}1920-22 \\
1930-32 \\
1936-38\end{array}$ & $\begin{array}{r}100 \\
73 \\
62\end{array}$ & $\begin{array}{r}100 \\
51 \\
55\end{array}$ & $\begin{array}{r}100 \\
79 \\
70\end{array}$ & $\begin{array}{r}100 \\
73 \\
51\end{array}$ & $\begin{array}{r}100 \\
83 \\
75\end{array}$ & $\begin{array}{r}100 \\
72 \\
57\end{array}$ & $\begin{array}{r}100 \\
59 \\
42\end{array}$ & $\begin{array}{r}100 \\
72 \\
61\end{array}$ & $\begin{array}{r}100 \\
75 \\
56\end{array}$ & $\begin{array}{r}100 \\
84 \\
61\end{array}$ \\
\hline
\end{tabular}




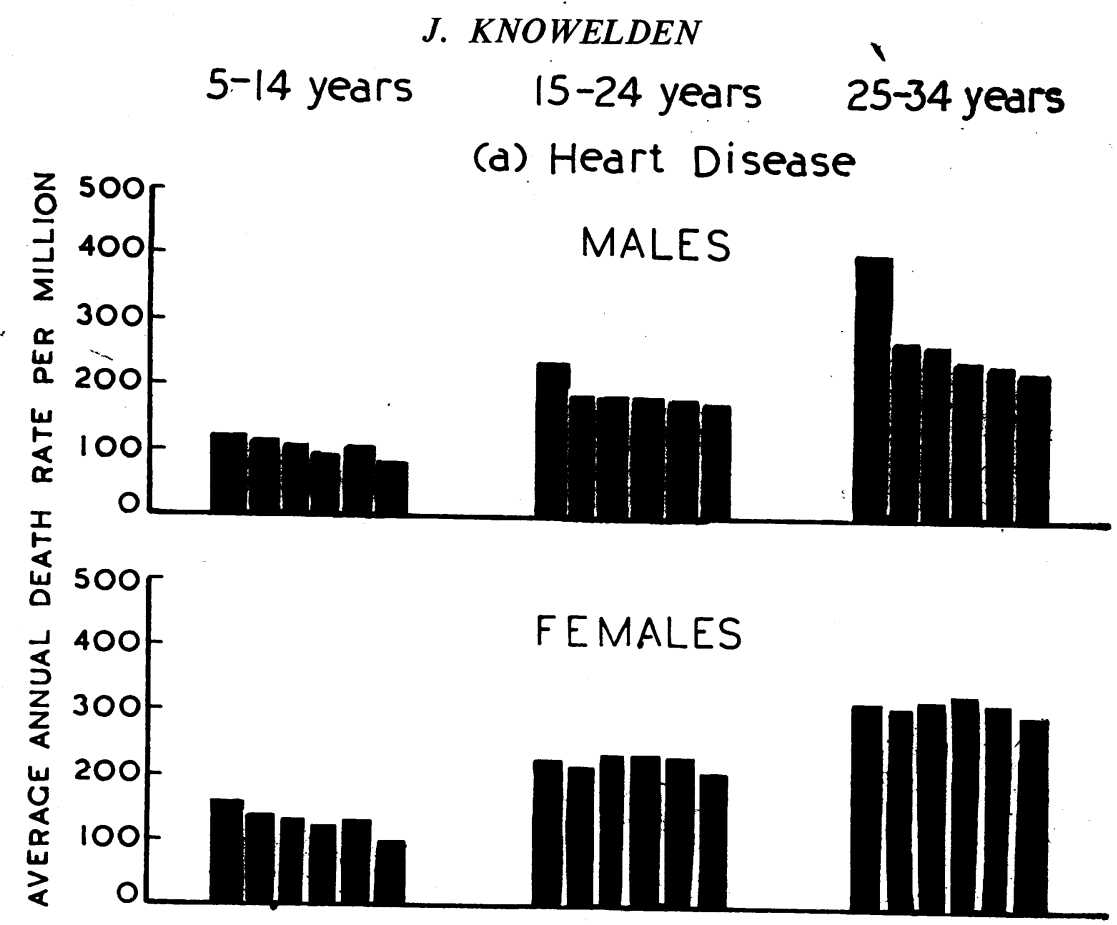

(b) Rheumatic Fever and Heart Disease

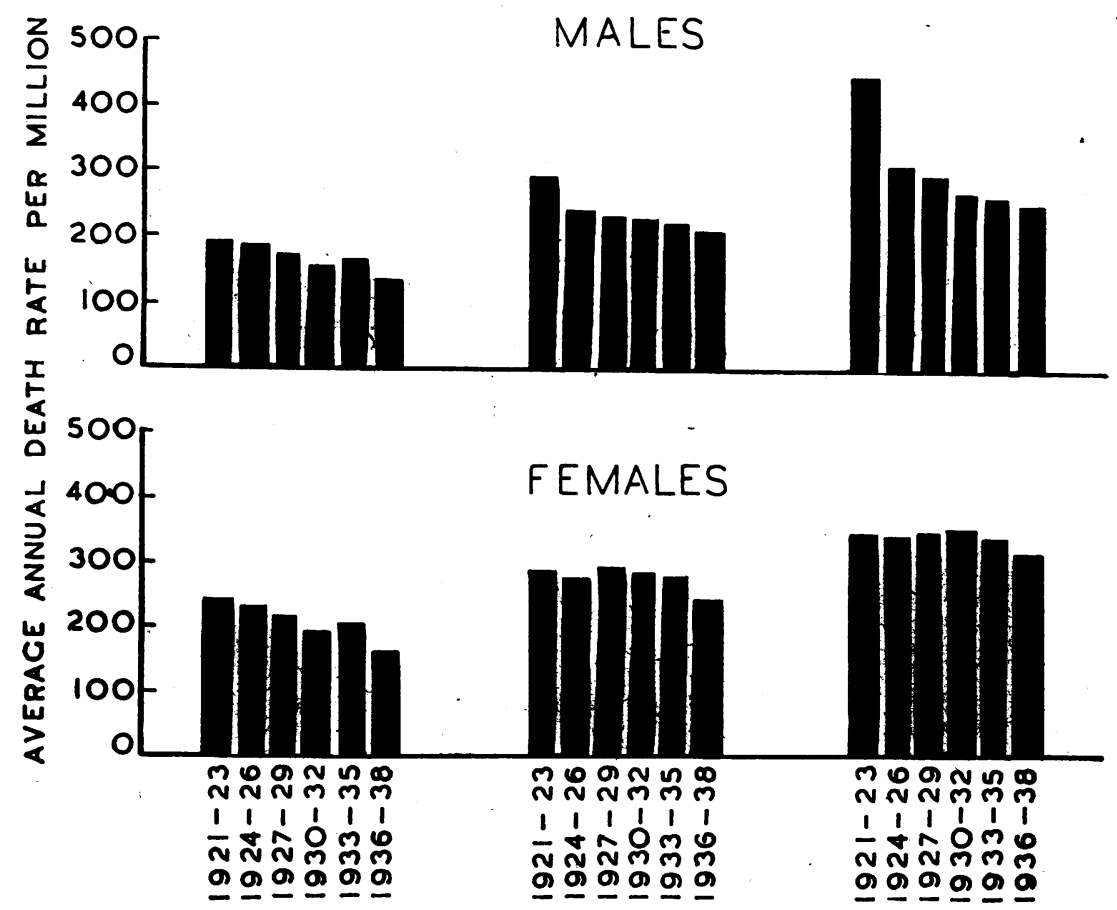

FIG. 2. -The trends in mortality from (a) heart disease, and $(b)$ rheumatic fever and heart disease in England and Wales, 1921-38, in age groups 5 to 14, 15 to 24, and 25 to 34 years. 
females, 25 to 34 ) followed, in order, by the County Boroughs, the other Urban Districts and the Rural Districts. The death rate of the rural areas is particularly low at ages 5 to 14, when it is only about one-half the rate in the large towns; this advantage falls with increasing age, but it is still considerable at ages 15 to 24 and, 25 to 34 . With the passage of time this order of mortality has not remained constant, but it appears that the changes lie almost entirely in the discrepant behaviour of the rates for London. The other types of areas show death rates for each sex, each age, and each period consistently in the order County Boroughs, Urban Districts, Rural Districts, and their rates of decline between 1920-22, 1930-32, and 1936-38 have, on the whole, been noticeable rather for their general consistency than for their divergencies (though an occasional divergence is apparent). Thus, taking the rates in 1936-38 as a percentage of the corresponding rates in 1920-22 for County Boroughs, Urban Districts, and Rural Districts gives (in that order) the following ratios: 5 to 14 : males, 70,51 , 75 , females, $61,56,61 ; 15$ to 24 : males, $75,68,71$, females, $98,83,87$; 25 to 34 : males, $54,53,45$, females, $89,92,85$. As was noted previously for the country as a whole, there has been in each of these aggregate of areas (a) a substantial fall in the death rate at the school ages, $(b)$ relatively little improvement for females either at ages 15 to 24 or at ages 25 to 34, (c) for males of these ages a sharp fall in mortality from the high, and possibly abnormal, rates of 1920-22 but only a very slight further decline between 1930-32 and 1936-38.

Turning to the County of London it will be seen that at school ages its relatively high death rate fell at first for both sexes more rapidly than the rates for the other administrative divisions; indeed between 1920-22 and 1930-32 its mortality was nearly halved. In the ensuing six years no further improvement is found for boys, but there was a still further considerable decline for girls. Passing to ages 15 to 24 , males again show a more rapidly falling death rate than is apparent for the country as a whole, but this improvement took place almost entirely up to 1930-32. On the other hand the death rate of young women from heart disease showed, in common with the rest of the country, virtually no change between 1920 and 1932 and then an abrupt - fall between 1932 and 1938 not apparent in the other areas. Finally, at ages 25 to 34 , there is no very material difference between the mortality trends of London and elsewhere though the rate has fallen slightly more in London than in the other large towns. As one result of these somewhat curious changes the death rates in London, which were in 1920-22 the highest, were in 1936-38 a little below those of the aggregate of the large provincial cities. There is no obvious reason why London should have been subject to such relatively high rates in 1920-22 nor why its trend of mortality should have departed so materially from the uniformity revealed by the other groups of areas. It might be thought that the answer to the second question might well lie in the special scheme for the treatment and care of cases of rheumatic fever introduced in 1926 by the London County Council. It is possible, however, to examine the mortality trends in the Greater London area within and without the scope

TABLE V

Mortality from Heart Disease, 15 to 24 years, in Administrative Regions of England and Wales in the TRIENNIA 1920-22, 1930-32, AND 1936-38

\begin{tabular}{|c|c|c|c|c|c|c|c|c|c|c|}
\hline & \multicolumn{5}{|c|}{ Males } & \multicolumn{5}{|c|}{ Females } \\
\hline & \multicolumn{5}{|c|}{ Average annual death rate per million persons living } & \multicolumn{5}{|c|}{ Average annual death rate per million persons living } \\
\hline & $\begin{array}{c}\text { England } \\
\text { and } \\
\text { Wales }\end{array}$ & $\begin{array}{l}\text { London } \\
\text { Adminis- } \\
\text { trative } \\
\text { County }\end{array}$ & $\begin{array}{l}\text { County } \\
\text { Boroughs }\end{array}$ & $\begin{array}{l}\text { Urban } \\
\text { Districts }\end{array}$ & $\begin{array}{c}\text { Rural } \\
\text { Districts }\end{array}$ & $\begin{array}{l}\text { England } \\
\text { and } \\
\text { Wales }\end{array}$ & $\begin{array}{c}\text { London } \\
\text { Adminis- } \\
\text { trative } \\
\text { County }\end{array}$ & $\begin{array}{c}\text { County } \\
\text { Boroughs }\end{array}$ & $\begin{array}{l}\text { Urban } \\
\text { Districts }\end{array}$ & $\begin{array}{c}\text { Rural } \\
\text { Districts }\end{array}$ \\
\hline \multirow[t]{2}{*}{$\begin{array}{l}1920-22 \\
1930-32 \\
1936-38\end{array}$} & $\begin{array}{l}252 \\
188 \\
177\end{array}$ & $\begin{array}{l}342 \\
211 \\
200\end{array}$ & $\begin{array}{l}285 \\
216 \\
213\end{array}$ & $\begin{array}{l}245 \\
185 \\
167\end{array}$ & $\begin{array}{l}167 \\
132 \\
118\end{array}$ & $\begin{array}{l}240 \\
234 \\
207\end{array}$ & $\begin{array}{l}293 \\
288 \\
194\end{array}$ & $\begin{array}{l}268 \\
270 \\
262\end{array}$ & $\begin{array}{l}227 \\
214 \\
188\end{array}$ & $\begin{array}{l}176 \\
166 \\
154\end{array}$ \\
\hline & \multicolumn{5}{|c|}{ Rate as percentage of $1920-22$ rate } & \multicolumn{5}{|c|}{ Rate as percentage of $1920-22$ rate } \\
\hline $\begin{array}{l}1920-22 \\
1930-32 \\
1936-38\end{array}$ & $\begin{array}{r}100 \\
74 \\
70\end{array}$ & $\begin{array}{r}100 \\
62 \\
58\end{array}$ & $\begin{array}{r}100 \\
76 \\
75\end{array}$ & $\begin{array}{r}100 \\
75 \\
68\end{array}$ & $\begin{array}{r}100 \\
79 \\
71\end{array}$ & $\begin{array}{r}100 \\
98 \\
86\end{array}$ & $\begin{array}{r}100 \\
98 \\
66\end{array}$ & $\begin{array}{r}100 \\
101 \\
98\end{array}$ & $\begin{array}{r}100 \\
94 \\
83\end{array}$ & $\begin{array}{r}100 \\
94 \\
87\end{array}$ \\
\hline
\end{tabular}


TABLE VI

Mortality from Heart Disease, 25 to 34 years, in Administrative Rkgions of England and Wales in the TRIENNIA 1920-22, 1930-32, AND 1936-38

\begin{tabular}{|c|c|c|c|c|c|c|c|c|c|c|}
\hline & \multicolumn{5}{|c|}{ Males } & \multicolumn{5}{|c|}{ Females } \\
\hline & \multicolumn{5}{|c|}{ Average annual death rate per million persons living } & \multicolumn{5}{|c|}{ Average annual death rate per million persons living } \\
\hline & $\begin{array}{c}\text { England } \\
\text { and } \\
\text { Wales }\end{array}$ & $\begin{array}{l}\text { London } \\
\text { Adminis- } \\
\text { trative } \\
\text { County }\end{array}$ & $\begin{array}{c}\text { County } \\
\text { Boroughs }\end{array}$ & $\begin{array}{c}\text { Urban } \\
\text { Districts }\end{array}$ & $\begin{array}{c}\text { Rural } \\
\text { Districts }\end{array}$ & $\begin{array}{c}\text { England } \\
\text { and } \\
\text { Wales }\end{array}$ & $\begin{array}{l}\text { London } \\
\text { Adminis- } \\
\text { trative } \\
\text { County }\end{array}$ & $\begin{array}{l}\text { County } \\
\text { Boroughs }\end{array}$ & $\begin{array}{c}\text { Urban } \\
\text { Districts }\end{array}$ & \begin{tabular}{|l} 
- Rural \\
Districts
\end{tabular} \\
\hline \multirow[t]{2}{*}{$\begin{array}{l}1920-22 \\
1930-32 \\
1936-38\end{array}$} & $\begin{array}{l}457 \\
243 \\
232\end{array}$ & $\begin{array}{l}537 \\
284 \\
240\end{array}$ & $\begin{array}{l}493 \\
275 \\
267\end{array}$ & $\begin{array}{l}435 \\
235 \\
230\end{array}$ & $\begin{array}{l}388 \\
181 \\
176\end{array}$ & $\begin{array}{l}339 \\
324 \\
297\end{array}$ & $\begin{array}{l}369 \\
360 \\
318\end{array}$ & $\begin{array}{l}391 \\
359 \\
347\end{array}$ & $\begin{array}{l}315 \\
314 \\
288\end{array}$ & $\begin{array}{l}267 \\
253 \\
227\end{array}$ \\
\hline & \multicolumn{5}{|c|}{ Rate as percentage of $1920-22$ rate } & \multicolumn{5}{|c|}{ Rate as percentage of $1920-22$ rate } \\
\hline $\begin{array}{l}1920-22 \\
1930-32 \\
1936-38\end{array}$ & $\begin{array}{r}100 \\
53 \\
51\end{array}$ & $\begin{array}{r}100 \\
53 \\
45\end{array}$ & $\begin{array}{r}100 \\
56 \\
54\end{array}$ & $\begin{array}{r}100 \\
54 \\
53\end{array}$ & $\begin{array}{r}100 \\
47 \\
45\end{array}$ & $\begin{array}{r}100 \\
96 \\
88\end{array}$ & $\begin{array}{r}100 \\
98 \\
86\end{array}$ & $\begin{array}{r}100 \\
92 \\
89\end{array}$ & $\begin{array}{r}100 \\
100 \\
92\end{array}$ & $\begin{array}{r}100 \\
95 \\
85\end{array}$ \\
\hline
\end{tabular}

of the Council's scheme. Table VII (for which I am indebted to Professor Bradford Hill, unpublished data) shows that at ages 5 to 14 and 15 to 24 the death rate has actually fallen rather more rapidly in areas outside the scheme than in the County areas within it. The fall in London appears, therefore, to be a local phenomenon and not easily explained.

\section{Mortality from Heart Disease in Specific COUNTY BOROUGHS}

In view of the fact that mortality has been found to be related to the degree of urbanization of the different areas, an attempt has been made to go a step further and to measure the importance of social and environmental factors in rheumatic heart disease. This has been done by correlating the heart disease mortality at ages 15 to 34 years in certain county boroughs with measurable conditions of their population. The factors 'selected were: (i) Social index, i.e. the proportion per 1,000 total employed males aged 14 years and over belonging to the Registrar-General's Social Classes IV and V. $\overrightarrow{0}$ (Registrar-General, 1934.)

(ii) Persons per room, 1931.

(iii) Number of persons per 1,000 living at a density of more than two persons per room, 1931.

(iv) Latitude.

The first three of these environmental measures $\stackrel{\circ}{\mathbb{D}}$ are based on the 1931 census of population (the latest available data for the purpose); the mortality rates have therefore been calculated for about the same time. It was found that there were so few deaths from heart disease in individual county boroughs at ages 5 to 14 years that reliable rates for this age group could not be cálculated. To obtain rates based on an adequate number of deaths (as far as possible not less than 20) the age groups 15 to 24 years and 25 to 34 years were combined to give one group 15 to 34 years, and a group of 30 county boroughs was selected by taking all those whose

TABLE VII

Death Rates from Heart Disease per Million living in London A.C. and the rest of Greater London

\begin{tabular}{|c|c|c|c|c|c|c|c|c|}
\hline & \multicolumn{4}{|c|}{$5-14$ years } & \multicolumn{4}{|c|}{$15-24$ years } \\
\hline & \multicolumn{2}{|c|}{ London A.C. } & \multicolumn{2}{|c|}{ Rest of Greater London } & \multicolumn{2}{|c|}{ London A.C. } & \multicolumn{2}{|c|}{ Rest of Greater London } \\
\hline & Death rate & $\%$ of $1921-22$ & Death rate & $\%$ of $1921-22$ & Death rate & $\%$ of $1921-22$ & Death rate & $\%$ of $1921-22$ \\
\hline $\begin{array}{l}1921-22 \\
1931-32 \\
1933-35 \\
1936-38\end{array}$ & $\begin{array}{r}205 \\
109 \\
148 \\
99\end{array}$ & $\begin{array}{r}100 \\
53 \\
72 \\
48\end{array}$ & $\begin{array}{r}160 \\
82 \\
93 \\
65\end{array}$ & $\begin{array}{r}100 \\
+51 \\
58 \\
41\end{array}$ & $\begin{array}{l}308 \\
249 \\
227 \\
197\end{array}$ & $\begin{array}{r}100 \\
81 \\
74 \\
64\end{array}$ & $\begin{array}{l}241 \\
184 \\
159 \\
131\end{array}$ & $\begin{array}{r}100 \\
76 \\
66 \\
54\end{array}$ \\
\hline
\end{tabular}




$$
\text { MALES }
$$

FEMALES

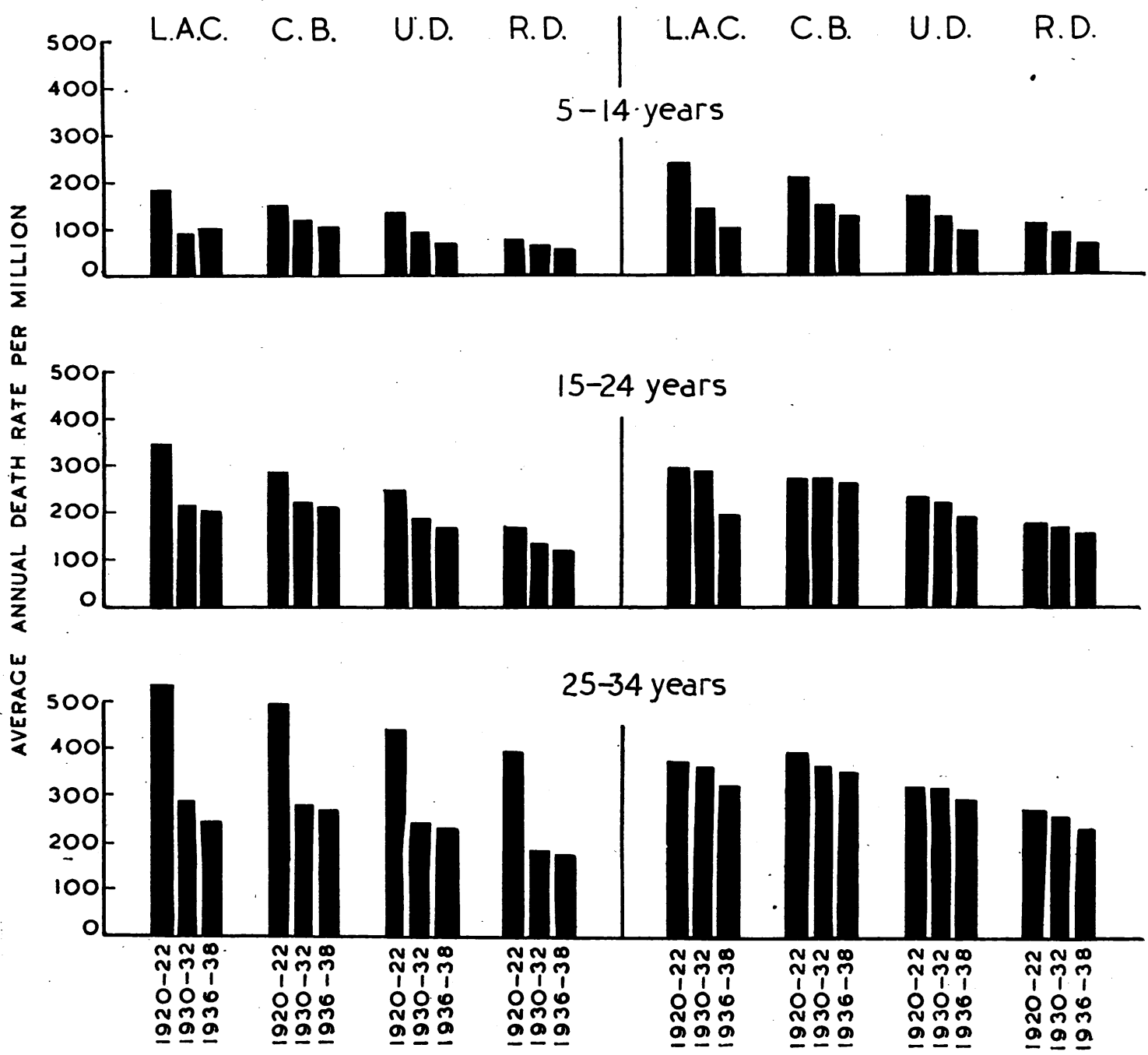

FIG. 3.-Mortality from heart disease in administrative divisions of England and Wales in the triennia 1920-23, $1930-32$, and $1936-38$ in age groups 5 to 14,15 to 24 , and 25 to 34 years.

populations in this age group were not less than 20,000 males and 20,000 females (the smallest town selected was Wolverhampton with a population at all ages of 133,190). A mean annual death rate, for males and females separately, was calculated by taking these deaths from heart disease age 15 to 34 in 1931, 1932, and 1933 and relating them to the 1931 census population in the same age group. (The triennium 1930-32 would have been preferable but in 1930 the deaths in this age group were not available.) The resulting rates for males varied from 64 per million in Brighton to 396 per million in Swansea, with an unweighted average for the 30 towns of 242 per million. For females the rates varied from 177 for Brighton to 496 per million for Middlesbrough, with an unweighted average of 320 (see Table VIII).

The correlation coefficients between these rates and the four environmental variables are shown in Table IX, together with the inter-correlations between the four social and environmental factors. themselves. The significance of the coefficients is 
shown both by their standard errors and by the " $t$ " test. The coefficients for males and females are, it will be seen, very similar, those between $(a)$ mortality and the social index, and $(b)$ between mortality and latitude, all being of the order $+0 \cdot 5$, and significant; with the two housing indices on the other hand, the coefficients were only about $0 \cdot 2$ to $\mathbf{0} \cdot 3$, and not significant. As would be expected, the inter-correlation coefficients between the four social and environmental indices were positive and significant, the lowest being that between persons per room and latitude, +0.44 , the highest +0.94 between the two housing indices. To allow for these relationships and to assess, so far as possible, the relative influence of the factors measured by the four indices, partial correlations were calculated and are shown in Tables $\mathrm{X}$ and XI.

The coefficient between male mortality and social index was +0.48 (Table IX). Keeping constant

TABLE VIII

Mortality from Heart Disease, at Ages 15 to 34 YEARS, IN THIRTY COUNTY BOROUGHS, 1931-33

\begin{tabular}{|c|c|c|c|}
\hline County Borough & Latitude & $\begin{array}{l}\text { Average } \\
\text { rate, } 1 \\
\text { million }\end{array}$ & $\begin{array}{l}\text { nual death } \\
-33 \text {, per } \\
\text { ons living }\end{array}$ \\
\hline & \multirow[b]{2}{*}{$\begin{array}{ll}50^{\circ} & 23^{\prime} \\
50^{\circ} & 48^{\prime} \\
50^{\circ} & 49^{\prime} \\
50^{\circ} & 55^{\prime} \\
51^{\circ} & 22^{\prime} \\
51^{\circ} & 27^{\prime} \\
51^{\circ} & 28^{\prime} \\
51^{\circ} & 32^{\prime} \\
51^{\circ} & 32^{\prime} \\
51^{\circ} & 37^{\prime}\end{array}$} & Males & Females \\
\hline $\begin{array}{l}\text { Plymouth .. } \\
\text { Portsmouth } \\
\text { Brighton .. } \\
\text { Southampton } \\
\text { Croydon . } \\
\text { Bristol } \\
\text { Cardiff } \\
\text { East Ham }\end{array}$ & & $\begin{array}{r}140 \\
149 \\
64 \\
181 \\
138 \\
183 \\
227 \\
224 \\
251 \\
396\end{array}$ & $\begin{array}{l}204 \\
262 \\
177 \\
203 \\
193 \\
274 \\
268 \\
342 \\
432 \\
322\end{array}$ \\
\hline $\begin{array}{l}\text { Coventry . } \\
\text { Birmingham } \\
\text { Wolverhampton } \\
\text { Leicester . . } \\
\text { Derby _. } \\
\text { Nottingham } \\
\text { Stoke-on-Tręnt }\end{array}$ & $\begin{array}{ll}52^{\circ} & 25^{\prime} \\
52^{\circ} & 29^{\prime} \\
52^{\circ} & 35^{\prime} \\
52^{\circ} & 39^{\prime} \\
52^{\circ} & 56^{\prime} \\
52^{\circ} & 57^{\prime} \\
53^{\circ} & 1^{\prime}\end{array}$ & $\begin{array}{l}193 \\
194 \\
274 \\
218 \\
244 \\
261 \\
346\end{array}$ & $\begin{array}{l}246 \\
265 \\
252 \\
289 \\
281 \\
342 \\
381\end{array}$ \\
\hline $\begin{array}{l}\text { Sheffield .. } \\
\text { Birkenhead } \\
\text { Liverpool .. } \\
\text { Manchester } \\
\text { Salford } \\
\text { Oldham } \quad . \\
\text { Bolton } \\
\text { Kingston-upon-Hul } \\
\text { Bradford } \\
\text { Leeds } \\
\text { Middlesbrough } \\
\text { Sunderland } \\
\text { Newcastle-on-Tyne }\end{array}$ & $\begin{array}{ll}53^{\circ} & 23^{\prime} \\
53^{\circ} & 23^{\prime} \\
53^{\circ} & 24^{\prime} \\
53^{\circ} & 29^{\prime} \\
53^{\circ} & 30^{\prime} \\
53^{\circ} & 33^{\prime} \\
53^{\circ} & 35^{\prime} \\
53^{\circ} & 45^{\prime} \\
53^{\circ} & \mathbf{4 8 ^ { \prime }} \\
53^{\circ} & \mathbf{4 8 ^ { \prime }} \\
54^{\circ} & 35^{\prime} \\
54^{\circ} & 55^{\prime} \\
54^{\circ} & 59^{\prime}\end{array}$ & $\begin{array}{l}309 \\
336 \\
319 \\
310 \\
219 \\
251 \\
304 \\
282 \\
204 \\
290 \\
259 \\
272 \\
212\end{array}$ & $\begin{array}{l}334 \\
339 \\
447 \\
349 \\
492 \\
479 \\
488 \\
262 \\
287 \\
352 \\
496 \\
241 \\
306\end{array}$ \\
\hline
\end{tabular}

the overcrowding rates, as measured by persons pero room, the coefficient is slightly reduced, to $+0 \cdot 39, ?$ but is still significant (Table $\mathrm{X}$ ). The corresponding coefficients for females are 0.54 and 0.47 , the latter:being still significant. Replacing persons per rooms by the other housing index, proportion at more than two persons per room, the partial coefficients between mortality and social index again remain significant at +0.42 for males and +0.53 fores females. There was, therefore, in these years an $\overrightarrow{0}$ association between the heart disease mortality of each sex in these 30 county boroughs and their social indices, a relationship which appeared to be almost independent of the overcrowding index of the towns.

Similarly, for both sexes, the observed relation- $-\vec{i}$ ships between heart disease mortality and latitudece are not greatly affected by assuming constant? housing indices in the 30 towns; the partial correla- tions are of the order of $+0 \cdot 45$, and significant,, while without constant housing indices " $r$ " was of the order of $+0 \cdot 5$. Although latitude and housing indices are significantly carrelated (Table IX), there_being in general a poor standard of housing in the northerly towns, the association between heart ${ }^{\circ}$ disease mortality and latitude cannot, it seems, be explained merely by these differences in housing standards.

Keeping constant the social index in these townsö the partial coefficients between mortality and $\mathbb{Q}$ latitude became +0.36 for males and +0.30 for $\overrightarrow{0}$ females, neither of which are technically significant. 3 On the other hand, the partial coefficients between mortality and social index, latitude being. kepto. constant, were +0.30 for males and +0.40 for females, the latter being significant.

Lastly, the association between mortality and the housing indices was, found to be weak, the coeffi 3 . cients being only $0 \cdot 2$ to $0 \cdot 3$. The partial coefficientso when social index or latitude in the 30 towns is kept constant are practically zero. The relationshipg between heart disease mortality and housing indices appears therefore to be fortuitous, being an expres sion of the bad housing conditions in the more northerly towns and their natural association with ${ }^{\circ}$ lower social classes. It seems that the housingo conditions per se had little effect on the mortality from rheumatic heart disease in these large towns.

In short, then, this analysis reveals no association in these 30 large towns between their mortality rates, from heart disease in 1931-33 and their concurrent? overcrowding indices, but a moderate and significanto degree of association between their mortality an $\bar{P}$. both their latitude and their proportion of persons belonging to the two classes lowest in the socias 
scale. Table XII broadly illustrates these associations by showing the unweighted average mortality rates in these 30 towns grouped according to their social index and their latitude. It will be seen that for females in all three latitude groups and for males in the most southerly and middle latitude groups the average mortality rate steadily increased as the proportion of employed males in the lowest social groups increased. For females the average mortality in the groups with social index under 350 and 350-399 increased with northerliness but for males this association held for the social index under 350 group and only partly for the other two groups.

It is difficult to tell exactly what is measured by the social index and therefore the meaning of its association with the heart disease mortality. In the depression years of the early 1930's there was considerable unemployment, particularly among the lower social classes, and although unemployment is not taken into account in the calculation of the social index it must have been considerable where there was a large proportion of the working population in classes IV and V. The correlation with the social index might indicate, therefore, a high rate of mortality where nutrition in a town was poor. Alternatively, an unfavourable social index might indicate lower standards of nursing and care of affected persons and therefore be correlated with increased mortality: There is nothing here to indicate whether a higher incidence or a higher fatality rate accounted for the higher mortality rates in some towns, though the studies in Bristol suggest that, where social and environmental conditions are poor, incidence is increased. Whether the fatality rate is also high cannot be determined.

The relationship between heart disease mortality and latitude was independent of the housing indices but was affected by variations in the social index. It is possible that if the social index were a better measure of the factors responsible for increased heart disease mortality, the correlation of mortality with latitude would have disappeared when the social index was kept constant. The coefficients were, in fact, not significant technically, but their uniformity suggests that latitude exerted some influence independent of overcrowding or social class. Behind it may, perhaps, lie a climatic factor and some aspect of poverty not comprised in the social index.

Further enquiry is clearly necessary to explain the relationships between heart disease mortality at these young ages, mainly rheumatic in origin, and social and environmental factors. The conflicting evidence from many authorities suggests that the answer is unlikely to lie in a single factor, that none such in isolation could account for the great local differences in the incidence of mortality. One of the chief obstacles to solving this and other

\section{TABLE IX}

Correlation Coefficients between Heart Disease Mortality, 15 to 34 Years, and Social and Environmental FACTORS IN 'THIRTY COUNTY BOROUGHS, 1931-33

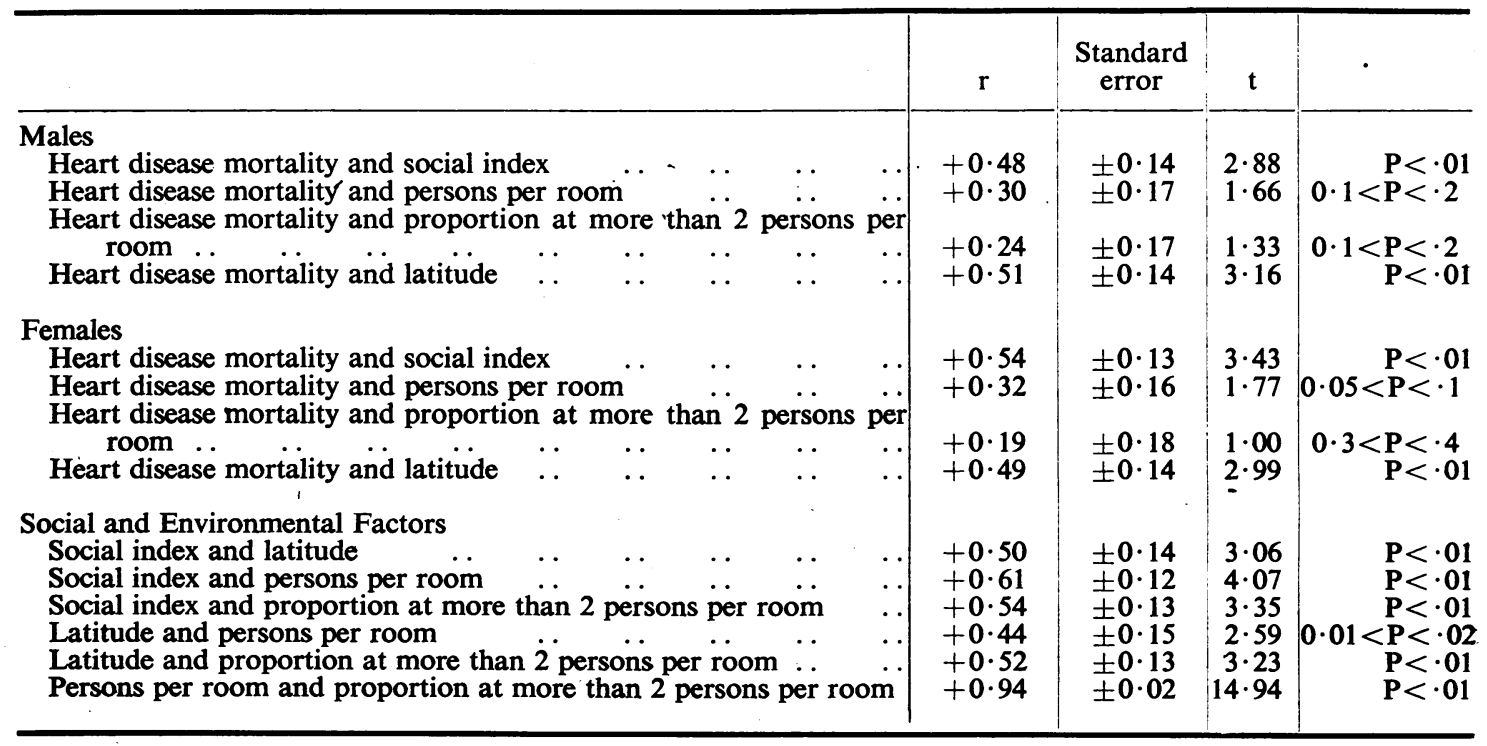


TABLE $X$

Partial Correlation Coefficients between Heart Disease Mortality in Males, 15 to 34 years, and Social and ENVIRONMENTAL FaCtors IN ThIRTY COUNTY BOROUGHs, 1931-33

\begin{tabular}{|c|c|c|c|c|c|}
\hline & Variable held constant & $\mathbf{r}$ & $\begin{array}{l}\text { Standard } \\
\text { error }\end{array}$ & $\mathbf{t}$ & \\
\hline 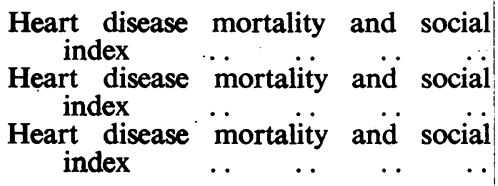 & $\begin{array}{l}\text { Persons per room } \\
\text { Proportion at more than } \\
2 \text { persons per room } \\
\text { Latitude }\end{array}$ & $\begin{array}{l}+0 \cdot 39 \\
+0 \cdot 42 \\
+0 \cdot 30\end{array}$ & $\begin{array}{l} \pm 0 \cdot 16 \\
\pm 0 \cdot 15 \\
\pm 0 \cdot 17\end{array}$ & $\begin{array}{l}2 \cdot 21 \\
2 \cdot 44 \\
1 \cdot 62\end{array}$ & $\begin{array}{c}0.02<\mathrm{P}<.05 \\
0.01<\mathrm{P}<.02 \\
0.1<\mathrm{P}<.2\end{array}$ \\
\hline $\begin{array}{l}\text { Heart disease mortality and latitude } \\
\text { Heart disease mortality and latitude . } \\
\text { Heart disease mortality and latitude ... }\end{array}$ & $\begin{array}{l}\text { Social index } \\
\text { Persons per room } \\
\text { Proportion at more than } \\
2 \text { persons per room }\end{array}$ & $\begin{array}{l}+0 \cdot 36 \\
+0.45 \\
+0.47\end{array}$ & $\begin{array}{l} \pm 0 \cdot 16 \\
\pm 0 \cdot 15 \\
\pm 0 \cdot 14\end{array}$ & $\begin{array}{l}2 \cdot 01 \\
2 \cdot 59 \\
2 \cdot 74\end{array}$ & $\begin{array}{l}0.05<\mathbf{P}<.1 \\
0.01<\mathbf{P}<.02 \\
0.01<\mathbf{P}<.02\end{array}$ \\
\hline 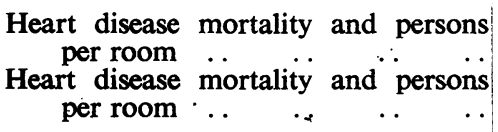 & $\begin{array}{l}\text { Social index } \\
\text { Latitude }\end{array}$ & $\begin{array}{l}+0 \cdot 01 \\
+0 \cdot 10\end{array}$ & $\begin{array}{l} \pm 0 \cdot 18 \\
\pm 0 \cdot 18\end{array}$ & $\begin{array}{l}0.06 \\
0.50\end{array}$ & $\begin{array}{l}\mathbf{0} \cdot \mathbf{3}<\mathrm{P} \\
\mathbf{0} \cdot \mathbf{3}<\mathrm{P}\end{array}$ \\
\hline $\begin{array}{l}\text { Heart disease mortality and proportion } \\
\text { at more than } 2 \text { persons per roorn } \\
\text { Heart disease mortality and proportion } \\
\text { at more than } 2 \text { persons per rocm }\end{array}$ & $\begin{array}{l}\text { Social index } \\
\text { Latitude }\end{array}$ & $\begin{array}{l}-0.02 \\
-0.03\end{array}$ & $\begin{array}{l} \pm 0 \cdot 18 \\
\pm 0 \cdot 18\end{array}$ & $\begin{array}{l}-0.09 \\
-0 \cdot 18\end{array}$ & $\begin{array}{l}\mathbf{0} \cdot \mathbf{3}<\mathrm{P} \\
\mathbf{0} \cdot \mathbf{3}<\mathrm{P}\end{array}$ \\
\hline
\end{tabular}

TABLE XI

Partial Correlation Coefficients between Heart Disease Mortality in Females, 15 to 34 years, and Social aND ENVIronmental Factors IN THIRTY COUNTY BOROUGHS, 1931-33

\begin{tabular}{|c|c|c|c|c|c|}
\hline & Variable held constant & $\mathbf{r}$ & $\begin{array}{l}\text { Standard } \\
\text { error }\end{array}$ & $\mathbf{t}$ & . \\
\hline 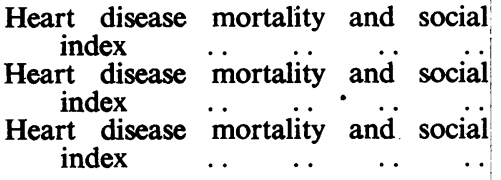 & $\begin{array}{l}\text { Persons per room } \\
\text { Proportion at more than } \\
2 \text { persons per room } \\
\text { Latitude }\end{array}$ & $\begin{array}{l}+0.47 \\
+0.53 \\
+0.39\end{array}$ & $\begin{array}{l} \pm 0 \cdot 14 \\
\pm 0 \cdot 13 \\
\pm 0 \cdot 15\end{array}$ & $3 \cdot 29$ & $\begin{array}{r}0.01<\mathrm{P}<.02 \\
\mathrm{P}<.01 \\
0.02<\mathrm{P}<.05\end{array}$ \\
\hline $\begin{array}{l}\text { Heart disease mortality and latitude .. } \\
\text { Heart disease mortality and latitude .. } \\
\text { Heart disease mortality and latitude .. }\end{array}$ & $\begin{array}{l}\text { Social index } \\
\text { Persons per room } \\
\text { Proportion at more than } \\
2 \text { persons per room }\end{array}$ & $\begin{array}{l}+0 \cdot 30 \\
+0.41 \\
+0 \cdot 47\end{array}$ & $\begin{array}{l} \pm 0 \cdot 17 \\
\pm 0 \cdot 15 \\
\pm 0 \cdot 14\end{array}$ & $\begin{array}{l}1 \cdot 64 \\
2 \cdot 36 \\
2 \cdot 77\end{array}$ & $\begin{array}{c}0.1<\mathbf{P}<.2 \\
0.02<\mathbf{P}<.05 \\
0.01<\mathbf{P}<.02\end{array}$ \\
\hline 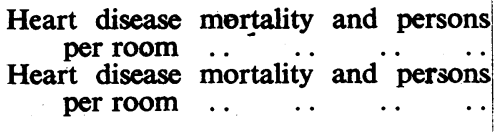 & $\begin{array}{l}\text { Social index } \\
\text { Latitude }\end{array}$ & $\begin{array}{l}-0.02 \\
+0.13\end{array}$ & $\begin{array}{l} \pm 0 \cdot 18 \\
\pm 0 \cdot 18\end{array}$ & $\begin{array}{r}-0 \cdot 11 \\
0.68\end{array}$ & $\begin{array}{l}0 \cdot 3<P \\
0 \cdot 3<P\end{array}$ \\
\hline $\begin{array}{l}\text { Heart disease mortality and proportion } \\
\text { at more than } 2 \text { persons per room } \\
\text { Heart disease mortality and proportion } \\
\text { at more than } 2 \text { persons per room }\end{array}$ & $\begin{array}{l}\text { Social index } \\
\text { Latitude }\end{array}$ & $\begin{array}{l}-0.15 \\
-0.09\end{array}$ & $\begin{array}{l} \pm 0 \cdot 18 \\
\pm 0 \cdot 18\end{array}$ & $\begin{array}{l}-0.78 \\
-0.49\end{array}$ & $\begin{array}{l}0 \cdot 3<P \\
0 \cdot 3<P\end{array}$ \\
\hline
\end{tabular}


TABLE XII

Unweighted Average Mortality Rate per Million from Heart Disease, Ages 15 to 34 years, 1931-33, in THIRTY COUNTY Boroughs GROUPED ACCORDING TO THEIR SOCIAL INDICES AND LATITUDE

\begin{tabular}{|c|c|c|c|c|c|c|}
\hline \multirow[b]{3}{*}{ - } & \multicolumn{3}{|c|}{ Males } & \multicolumn{3}{|c|}{ Females } \\
\hline & \multicolumn{3}{|c|}{ Social index } & \multicolumn{3}{|c|}{ Social index } \\
\hline & Under 350 & $350-399$ & Over 400 & Under 350 & $350-399$ & Over 400 \\
\hline $\begin{array}{l}\text { Latitude S. of } 52^{\circ} \mathrm{N} \\
\text { Latitude } 52^{\circ} \mathrm{N} .53^{\circ} 20^{\prime} \mathrm{N} \\
\text { Latitude N. of } 53^{\circ} 20^{\prime} \mathrm{N} \text {. }\end{array}$ & $\begin{array}{l}166 \\
212 \\
290\end{array}$ & $\begin{array}{l}218 \\
267 \\
265\end{array}$ & $\begin{array}{l}251 \\
346 \\
281\end{array}$ & $\begin{array}{l}241 \\
270 \\
352\end{array}$ & $\begin{array}{l}261 \\
297 \\
374\end{array}$ & $\begin{array}{l}432 \\
381 \\
379\end{array}$ \\
\hline
\end{tabular}

similar problems is the absence of a reliable method of accurately measuring such fundamental features as poverty and housing conditions, though there is good reason to suspect their influence. Until the indices of social and environmental conditions are improved the true measures of associations must remain undetermined.

\section{SUMMARY}

An analysis has been made for England and Wales, and its administrative areas, of the mortality at ages 5 to 14,15 to 24 , and 25 to 34 years due to rheumatic fever and heart disease, the preponderance of the latter at these ages being directly attributable to rheumatic fever. Between 1921-23 and 1936-38, the period of years covered by this study, the total mortality from rheumatic fever and heart disease shows a substantial decline for both sexes at the school ages 5 to 14 . On the other hand, at the ages of adolescence and young adult life, 15 to 34 , the fall in mortality has been very slight and disappointing since 1924-26. This trend (measured on heart disease only) is uniformly apparent in the aggregates of each of the broad administrative areas of the country-county boroughs, urban districts, rural districts. The County of London reveals a rather divergent experience. From a relatively high level in 1920-22 its death rates, particularly at ages 5 to 14 and 15 to 24 , have shown a greater degree of improvement than the rest of the country. It is not possible to attribute this to the operation of the Special Scheme introduced by the London County Council, since the fall in mortality has been equally great in areas of Greater London outside this Scheme.
It appears, therefore, to be a local change, not easily explained.

In general, mortality increases with the degree of urbanization, the rates for rural areas being appreciably below those of the large towns, and it falls more heavily on girls and young women than on boys and young men. The mortality from heart disease at ages 15 to 34 in thirty large towns has been correlated with indices of their social and environmental features. No relationship is apparent between mortality and overcrowding, but a moderate degree of association is found between the death rate and the proportion of employed males belonging to the lowest social classes and with the latitude of the city.

I wish to thank Prof. A. Bradford Hill for much helpful advice, and Mrs. Young who kindly drew the diagrams.

\section{REFERENCES}

Clarke, P. J. Holland (1940). Irish J. med. Sci., 171, 97. Daniel, G. H. (1943). Bristol med.-chir. J., 60, 13. Glover, J. A. (1943). Lancet, 2, 51. (1946). Monthly Bull. Min. Hith., 5, 222.

Medical Research Council (1927). "Child Life Investigations, Social conditions and acute rheumatism." Spec. Rep. Ser. Med. Res. Coun., Lond. No. 114.

Ministry of Health (1927). "Acute rheumatism in children in its relation to heart disease." Rep. publ. hlth. med. subj., Lond. No. 44.

Morris, J. N., and Titmuss, R. M. (1942). Lancet, 2, 59.

Parkinson, J. (1945). Lancet, 2, 657.

Perry, C. B., and Roberts, J. A. F. (1937). Brit. med. J., 2, Suppl. p. 154.

Registrar-General (1934). “ "Statistical Review, England and Wales." Text, p. 150.

Ryle, J. A. (1946). J. R. San. Inst., 66, 277.

Savage, W. G. (1931). Brit. med. J., 2, Suppl. p. 37.

Wilson, May G. (1940). "Rheumatic Fever." The Commonwealth Fund, New York. 